\title{
PENGGUNAAN MEDIA GAMBAR UNTUK MENGEMBANGKAN PENGUASAAN KOSAKATA PADA ANAK AUTIS USIA DINI
}

\author{
Ikhya Ulumudin \\ e-mail: ikhya.puslitjak@gmail.com
}

\author{
Peneliti pada Pusat Penelitian Kebijakan Pendidikan dan Kebudayaan, Kemendikbud \\ Jalan Jenderal Sudirman - Senayan, Jakarta
}

\begin{abstract}
Abstrak: Anak usia dini dengan autisme yang mengalami keterlambatan dalam berkomunikasi , dapat menjadi sedih, marah, atau frustasi ketika tidak dapat mengomunikasikan keinginan atau kebutuhannya. Untuk itu, perlu dicari solusi untuk mengatasi permasalahan tersebut, sehingga la dapat berkomunikasi seperti anak pada umumnya. Tujuan penelitian ini adalah untuk mengetahui pengaruh penggunaan media gambar dalam mengembangkan penguasaan kosakata pada anak usia dini dengan autisme. Penelitian ini merupakan studi kasus modifikasi perilaku dengan subjek tunggal. Teknik pengumpulan data menggunakan observasi. Subjek penelitian adalah seorang anak berinisial AZH berusia 4 tahun 10 bulan. Adapun instruktur dalam melakukan treatment adalah peneliti dan ibu dari AZH. Pelaksanaan penelitian dilakukan pada tanggal 1 - 27 Februari 2019 dengan frekuensi treatment sebanyak 20 kali yang bertempat di rumah orangtua AZH di Kota Depok - Jawa Barat. Simpulan hasil penelitian ini memperlihatkan bahwa penggunaan media gambar dapat mengembangkan penguasaan kosakata pada anak usia dini dengan autisme. Hal ini dapat ditunjukkan dari kemampuan AZH dalam menguasai seluruh kosakata (26 kosakata) yang diberikan dengan waktu 27 hari. Saran dalam penelitian ini yakni pemberian treatment untuk mengembangkan penguasaan kosakata pada anak usia dini dengan autisme melalui media gambar sebaiknya kosakata yang diberikan pertama kali yakni kata benda dengan dua suku kata dan empat huruf. Selain itu, usahakan anak tersebut diperlihatkan benda aslinya sesuai dengan gambar yang ditunjukkan.
\end{abstract}

Kata-kata kunci: anak autis usia dini, kosakata, media gambar.

\section{UTILIZING PICTURES AS MEDIA TO DEVELOP VOCABULARIES MASTERY FOR A CHILD WITH AUTISM}

\begin{abstract}
Children with autism can experience slower development in communication skill in their early years. This difficulty in communication makes them prone to easily be sad, upset, or frustrated when they are unable to communicate what they want or need. Therefore, a solution to overcome this communication problem is needed to make sure they could develop language skills and unhindered communication with others as much as the children with no autism. This research aims to find out how using pictures as media affect the development of vocabularies mastery for children with autism. The method used was conducting a single subject, while data was collected through observation. The subject for this research was a child with initials of $A Z H$ aged 4 years 10 months old. The instructors of treatment for the research is the researcher of this study and the mother of $A Z H$. The observation was conducted from February 1st to 27th, 2019 with 20 times treatment frequency. This was done in AZH home in Depok, West Java. This research concluded that using pictures as media has effect in improving autistic children's mastery of vocabularies. This was evident in AZH's ability to master all 26 vocabularies taught in the 27 days of study. This research suggests a periodic treatment to develop the mastery of vocabularies in autistic children through pictures, and the vocabularies taught should start with nouns with two syllables and four letters. Besides, it is encouraged to show them the real objects corresponding with the pictures shown.
\end{abstract}

Keywords: Autistic Children, Vocabularies, Pictures. 


\section{PENDAHULUAN}

Pemakaian istilah autis kepada penyandang diperkenalkan pertama kali oleh Loe Kanner, seorang psikiater dari Harvard pada tahun 1943. Berdasarkan pengamatan terhadap 11 orang penyandang terdapat banyak sekali persamaan gejala pada anak autis namun yang sangat menonjol adalah gejala kesulitan berinteraksi dengan orang lain, mengisolasi diri, sangat asik dengan diri sendiri seolah-olah ia hidup dalam dunianya sendiri, dan cara berkomunikasi yang aneh. Kata autis berasal dari bahasa Yunani "auto" yang berarti berdiri sendiri (Putri, 2008).

Autis disebut pula sebagai Autism Spectrum Disorders (ASD). Autis disebut gangguan spektrum karena tingkat dan bentuk yang dimiliki oleh setiap anak dengan autis berbeda-beda. Setiap anak dengan autis memiliki karekteristik yang unik. Kemampuan dan keterbatasan seorang anak dengan autis bukan merupakan indikasi dari kemampuan dan keterbatasan yang sama pada anak dengan autis yang lain. Menurut Diagnostic and statistical mental disorders (DSM-1V), gejala klinik dari autis yaitu hambatan komunikasi, interaksi sosial, dan minat terbatas seta perilaku repetitif (Hidayah, 2017).

Hasil penelitian Boham (2013), menyatakan bahwa beberapa permasalahan yang secara umum terdapat pada anak dengan gangguan autis adalah pada aspek sosial dan komunikasi. Sementara itu, Wijayakusuma (2008) menguraikan beberapa karakteristik, yaitu komunikasi, sosialisasi, perilaku, dan kelainan penginderaan. Dalam hal komunikasi, anak dengan autis mengalami kesulitan dalam berbicara atau berbahasa. Biasanya komunikasi hanya dapat dilakukan menggunakan bahasa tubuh, dalam jangka waktu yang tidak lama. Sosialisasi anak dengan autis mengalami hambatan karena cenderung menghabiskan waktunya untuk menyendiri. Mereka tidak mempunyai ketertarikan untuk berteman atau bersosialisasi dengan lingkungan sekitar. Bahkan, tidak ada respon yang ditunjukkan ketika orang lain mengajaknya berkomunikasi.

Salah satu hambatan pada anak autis yakni komunikasi. Menurut Suprapto (2009) komunikasi merupakan proses transfer informasi atau pesan dari pengirim pesan sebagai komunikator dan kepada penerima sebagai komunikan. Proses komunikasi tersebut bertujuan untuk mencapai saling pengertian antar dua pihak yang terlibat dalam proses komunikasi. Anak autis biasanya mengalami keterlambatan dalam berkomunikasi saat masih balita, diantaranya keterlambatan mengoceh, berbicara, dan memahami bahasa tubuh. Beberapa anak autis bahkan menunjukkan kemampuan mengoceh, namun beberapa bulan kemudian kemampuan tersebut menghilang.

Anak autis memiliki keterampilan komunikasi yang sangat beragam. Anak dengan autis seringkali sulit untuk diajak komunikasi secara verbal. Hal tersebut bukan berarti anak tidak bisa berkomunikasi. Anak dengan autis bisa jadi kurang memiliki cara untuk berkomunikasi. Selain itu, anak dengan autis mengalami kesulitan dalam bicara atau berbicara secara spontan. Anak akan lebih nyaman apabila terlibat dalam komunikasi yang terstruktur.

Kesulitan dalam berkomunikasi pada anak autis dapat membuat anak menjadi sedih atau frustasi ketika tidak dapat mengomunikasikan keinginan atau kebutuhannya. Komunikasi yang dilakukan anak autis bertujuan untuk memperoleh keinginan dan kebutuhannya, bukan untuk menciptakan dan menjalin hubungan sosial. Anak autis mungkin tidak akan merespon hal yang orang katakan seperti nama, atau acuh tak acuh terhadap setiap upaya yang dilakukan orang lain untuk berkomunikasi bersama mereka (Hidayah, 2017). Untuk dapat berkomunikasi anak autis memerlukan perbendaharaan kosakata yang memadai. Salah satu strategi pendekatan yang mampu mengembangkan kosakata anak autis yakni dengan menggunakan media visual/gambar.

Anak autis adalah pembelajar visual. Untuk itu dalam mempermudah anak autis menguasai kosakata dengan menggunakan media visual. Media visual adalah salah satu jenis media pembelajaran yang dapat digunakan dalam proses belajar pada anak autis. Media visual ini dapat memperlancar pemahaman dan memperkuat ingatan. Selain itu media visual dapat pula menumbuhkan minat anak dan dapat memberikan hubungan antara isi materi pelajaran dengan dunia nyata (Arsyad, 2010).

Untuk itu penggunaan media visual sangat penting dalam proses penguasaan kosakata khususnya bagi anak autis. Penguasaan kosakata penting bagi anak autis agar dapat berkomunikasi dan berinteraksi dengan lingkungannya. Dengan mempunyai perbendaharaan kosakata yang memadai, akan memperlancar anak autis dalam bersosialisasi, bahkan dapat mengikuti pembelajaran di kelas dengan baik pula. Hal ini karena penguasaan kosakata akan mempermudah dalam memahami bahasa yang terdapat dalam buku-buku pelajaran. Selain itu, penguasaan kosakata akan meningkatkan 
kemampuan komunikasi anak autis, sehingga la dapat menerima, memahami, mengidentifikasi, dan merespons informasi yang diterimanya dan kemudian anak autis dapat menyampaikan kembali informasi tersebut melalui lisan atau tulisan dengan menggunakan bahasa yang dipahami oleh lawan bicaranya.

Para pakar autis menyatakan bahwa mereka (anak autis) melihat kata-kata dan mendengar bahasa dalam bentuk gambar di benak mereka (Freed dan Parsons, 1997). Mereka menerjemahkan perkataan orang-orang yang berkomunikasi dengan mereka menjadi film dalam benak mereka. Itulah sebabnya, mengapa penggunaan alat bantu visual berupa foto terdengar masuk akal. Gambar juga membantu meredakan kecemasan anak pengidap autis terhadap hal-hal yang tidak mereka kenal. Hal ini terutama berlaku ketika la berada dalam situasi dan kondisi yang belum pernah dijumpai sebelumnya. Gambar adalah alat bantu visual yang efektif dalam berkomunikasi pada anak autis. Gambar membantu anak autis untuk mengetahui apa yang ada dalam dunianya ketika anak autis berupaya memahami rangsangan yang diterimanya. Gambar merupakan dasar komunikasi yang baik untuk anak autis sebelum menggunkan simbol (Kidd, 2013).

Terapi wicara melalui media visual (gambar) dilakukan secara dua arah, terapis harus mempunyai keahlian sebagai komunikator yang baik, serta pemberian reward dan punishment terhadap apa yang direspon oleh anak yang diterapi. Hal ini sejalan dengan hasil penelitian yang dilakukan oleh Sitompul (2013) yang menyebutkan bahwa proses komunikasi yang baik dilakukan dengan dua arah dan didominasi oleh bahasa non-verbal. Sedangkan, masing-masing terapis mendominasi untuk menjadi komunikator. Hambatan komunikasi yang ditemukan adalah hambatan psikologis dan semantik. Reward and punishment diberikan sebagai respon atas pesan komunikasi yang disampaikan oleh komunikan kepada komunikator sekaligus sebagai etika yang diberlakukan untuk menjadi salah satu aspek untuk memotivasi murid autis untuk semakin semangat dalam melakukan proses terapi wicara.

Kesulitan dalam berkomunikasi pada anak autis dapat membuat anak menjadi sedih, marah bahkan menjadi frustasi. Untuk mengatasi permasalahan komunikasi pada anak autis agar dapat berkomunikasi seperti anak pada umumnya, dapat dibantu dengan media visual karena memang anak autis adalah pembelajar visual. Berkaitan dengan itu, maka judul dalam penelitian ini adalah "Penggunaan media gambar untuk mengembangkan penguasaan kosakata pada anak autis". Tujuan penelitian ini adalah untuk mengetahui pengaruh penggunaan media gambar dalam meningkatkan penguasaan kosakata pada anak autis. Adapun indikatornya adalah untuk: (i) Mengetahui perkembangan pengucapan kosakata; (ii) Mengetahui tingkat kesulitan dalam mengucapkan kosakata. (iii) Mengetahui tingkat kesulitan dalam mengingat kosakata; dan (iv) Mengetahui perkembangan durasi waktu melakukan Treatment. Manfaat penelitian ini dapat digunakan oleh orangtua, terapis, maupun guru sebagai bahan referensi dalam mengembankan penguasaan kosakata pada anak autis melalui media visual.

\section{METODE PENELITIAN}

Penelitian ini merupakan studi kasus modifikasi perilaku untuk subjek tunggal pada satu orang anak autis usia dini. Dalam bahasa kedokteran atau medis treatment disebut "terapi". Merujuk Juang Sunanto dkk (2005), modifikasi perilaku dapat dilakukan untuk memperoleh kemampuan tertentu secara sadar dan bersifat relatif permanen, termasuk dalam penguasaan kosakata. Pada penelitian ini modifikasi perilaku dilakukan dengan penggunaan media gambar untuk mengembangkan penguasaan kosakata pada anak autis.

Media gambar yang digunakan berstandar khusus untuk anak autis yang mempunyai kriteria: (i) pada setiap kosakata terdapat huruf pertamanya; (ii) pada setiap kosakata terdapat kata dalam bentuk huruf; dan (iii) pada setiap kosakata terdapat gambar sesuai dengan kosakatanya.

Teknik pengumpulan data dilakukan dengan observasi melalui instrumen pedoman observasi. Pedoman observasi bertujuan untuk mengetahui hasil dari perlakuan penggunaan media gambar dalam mengembangkan penguasaan kosakata pada anak autis usia dini. Pedoman observasi berisikan tentang daftar kosa kata yang dimulai dari huruf $A$ sampai $Z$, tanggal dan waktu pelaksanaan treatment, durasi waktu pelaksanaan treatment, dan jumlah instruksi pada setiap kosakata.

Subjek penelitian adalah seorang anak berinisial $\mathrm{AZH}$, berusia 4 tahun 10 bulan yang telah di diagnosa autis oleh dokter pada usia 2 tahun 8 bulan. AZH mengalami kesulitan dalam mengucapkan kosakata, bahkan ketika diajarkan untuk mengucapkan suatu 
kosakata dia tidak mau mengucapkan dan menghiraukan instruksi baik dari orangtuanya maupun dari terapisnya. Kosakata yang keluar dari mulutnya hanyalah kosakata yang terdapat pada lagu yang pernah didengarnya, namun dia tidak mengetahui maknanya. Sebagai contoh, dia sering mengucapkan "balonku ada lima atau tinkle-tinkle little star" namun dia tidak mengetahui maknanya. Nyanyian tersebut biasanya dilakukan ketika dia sedang marah. Adapun instruktur dalam melakukan treatment adalah peneliti dan dibantu oleh ibu dari $\mathrm{AZH}$. Instrukur dalam dunia kedokteran/medis sering disebut dengan terapis, namun karena ini adalah penelitian sehingga kata terapis berubah menjadi instruktur.

Pelaksanaan penelitian dimulai tanggal $1-27$ Februari 2019 dengan jumlah treatment sebanyak 20 kali. Waktu pelaksanaan treatment disesuaikan dengan kondisi psikologis anak yakni ketika dalam kondisi tenang. Hal ini karena jika dalam kondisi tidak tenang, $\mathrm{AZH}$ tidak memperhatikan dan tidak terjadi kontak mata antara anak dengan gambar yang diberikan, sehingga $\mathrm{AZH}$ tidak mengikuti instruksi yang diberikan oleh instruktur bahkan memberontak sampai menangis. Dalam setiap melakukan treatment dibutuhkan sebanyak dua orang, yakni satu orang sebagai instruktur dan satunya lagi mencatat hasil dari treatment sekaligus membantu dalam menenangkan AZH. Adapun tempat melakukan penelitian berada di rumah orangtua AZH di daerah Kota Depok.

Langkah dalam melakukan setiap melakukan treatment terbagi menjadi lima langkah. Pertama, instruktur memperlihatkan gambar ke depan mata AZH dengan jarak sekitar $50 \mathrm{~cm}$; Kedua, setelah AZH memperhatikan gambar, instruktur mengucapkan dengan lantang huruf kemudian kosakatanya. Sebagai contoh "AApi"; Ketiga, jika AZH belum mengucapkan apa yang telah diinstruksikan, instruktur kembali mengucapkan huruf dan kata tersebut sampai empat kali dan jika sampai empat kali AZH belum mengucapkan dilanjutkan ke kosakata selanjutnya; Keempat, jika $\mathrm{AZH}$ dapat mengikuti/mengucapkan kosakata yang diintruksikan, maka diberikan reward oleh instruktur berupa bahasa non-verbal (misalkan tepuktangan, mengacungkan jempol, dll), bahasa verbal (misalkan kata hebat, hore, dan lain-lain), atau makanan yang disukainya; Kelima, setelah dirasa hafal, dalam melakukan treatment instruktur hanya mengucapkan hurufnya saja, kemudian AZH mengucapkan katanya. Misalnya, instruktur mengucapkan huruf " $A$ " lalu $A Z H$ langsung mengucapkan "Api”. Namun jika, AZH tidak merespon, instruktur baru menyebutkan kosakatanya juga.

Teknik analisis data antara lain: (i) Untuk mengetahui perkembangan pengucapan kosakata yakni dengan melihat kemampuan $\mathrm{AZH}$ dalam mengucapkan kosakata sebelum dilakukan treatment dan sesudahnya. Selain itu dilakukan perbandingan kejelasan pengucapan kosakata pada treatment pertama dan terakhir; (ii) untuk mengetahui tingkat kesulitan dalam mengucapkan kosakata yakni dengan melihat ketepatan dan kejelasan kosakata (iii) untuk mengetahui tingkat kesulitan mengingat kosakata yakni dengan melihat jumlah instruksi pada setiap kosakata; dan (iv) untuk mengetahui perkembangan durasi waktu melakukan treatment yakni dengan melihat waktu yang dibutuhkan pada setiap treatment.

\section{HASIL DAN PEMBAHASAN}

\section{HASIL}

Treatment penggunaan media gambar untuk mengembangkan penguasaan kosakata pada $\mathrm{AZH}$ dilakukan sebanyak 20 kali. Sedangkan jumlah kosakata yang harus diberikan untuk dihafal sejumlah 26 kosakata. Kosakata tersebut disusun dari huruf $A-Z$ yang dimulai dengan huruf A dengan kata "Api" dan diakhiri dengan huruf Z dengan kata "Zaitun". Sebenarnya dalam melakukan treatment lebih dari 20 kali, namun dalam penelitian ini yang dicatat hanya yang berhasil melakukan melakukan sampai selesai (26 kosakata). Berikut ini adalah tabel perkembangan pengucapan $\mathrm{AZH}$ pada pemberian treatment pertama dan terakhir.

\begin{tabular}{|c|l|l|l|l|l|l|l|}
\hline NO & \multicolumn{1}{|c|}{ KATA DAN GAMBAR } & TREATMENT (Ke-1) & $\begin{array}{c}\text { TREATMENT } \\
(\text { Ke-20) }\end{array}$ & NO & $\begin{array}{c}\text { KATA DAN GAMBAR } \\
\text { (Ke-20) }\end{array}$ & $\begin{array}{c}\text { TREATMENT } \\
(\text { Ke-1) }\end{array}$ \\
\hline 1 & Api & Api & Api & 14 & Nenek & nene \\
\hline 2 & Bendera & Benena & Benena & 15 & Odol & odo \\
\hline 3 & Celana & cenana & cena & 16 & Pohon & poho & poho \\
\hline 4 & Daun & dau & doho & 17 & Quran & kukwa \\
\hline 5 & Ember & ebe & ebe & 18 & Robot & dobo & wobo \\
\hline 6 & Foto & gofo & fofo & genas & 20 & Tangga & sisi \\
\hline 7 & Gelas & & tana & tata \\
\hline
\end{tabular}




\begin{tabular}{|c|l|l|l|l|l|l|l|}
\hline NO & \multicolumn{1}{|c|}{ KATA DAN GAMBAR } & TREATMENT (Ke-1) & $\begin{array}{c}\text { TREATMENT } \\
(\text { Ke-20) }\end{array}$ & NO & \multicolumn{1}{|c|}{$\begin{array}{c}\text { KATA DAN GAMBAR } \\
(\text { Ke-20) }\end{array}$} & $\begin{array}{c}\text { TREATMENT } \\
(\text { Ke-1 })\end{array}$ \\
\hline 8 & Harimau & hamimo & hamimo & 21 & Ulat & uma \\
\hline 9 & lkan & ika & ika & 22 & Vitamin & vave \\
\hline 10 & Jaket & jake & jake & 23 & Wajan & vimani \\
\hline 11 & Kursi & kusi & kusi & 24 & Xilofon & waja & sadofo \\
\hline 12 & Lilin & lili & nini & 25 & Yoyo & sipapo \\
\hline 13 & Mawar & mama & mamat & 26 & Zaitun & yoyo & zeyo \\
\hline
\end{tabular}

\section{Perkembangan Pengucapan Kosakata}

Sebelum melakukan treatment, AZH belum mampu mengucapkan 26 kosakata yang diberikan pada saat treatment. Pada treatment pertama kali AZH sudah mampu mengikuti seluruh kosakata yang diucapkan oleh instruktur, walaupun masih banyak kosakata yang diucapkan kurang jelas atau kurang tepat dengan apa yang seharusnya diucapkan. Misalkan instruktur mengucapkan "Bendera" AZY mengikuti dengan ucapan "Benena". Hal ini dinilai wajar, mengingat salah satu ciri anak autis mempunyai kemampuan pelafalan kosakata yang kurang tepat/ jelas. Selain pengucapannya belum jelas, pada treatment pertama kali $\mathrm{AZH}$ belum mampu mengingat kosakata yang telah diberikan oleh instruktur.

Perubahan ketepatan pengucapan kosakata dari treatment pertama dibandingkan dengan treatment terakhir yang diberikan kepada $\mathrm{AZH}$ dapat dikelompokan menjadi 4 bagian, diantaranya: pelafalnnya tidak berubah, pelafalannya berubah semakin lebih baik, pelafalannya berubah menjadi kurang baik, dan pelafalannya berubah namun tidak dapat dikatakan lebih baik atau lebih tidak baik (lihat tabel 1).

Terdapat kosakata yang diucapkan oleh AZH pelafalannya tidak berubah dari treatment pertama dibandingkan dengan treatment terakhir. Dari 26 kosakata, terdapat 14 (54\%) kosakata yang pelafalannya tidak berubah, diantaranya: api diucapkan "Api", bendera diucapkan "Benena", ember diucapkan "Ebe, foto diucapkan "Fofo", harimau diucapkan "Hamimo", ikan diucapkan "Ika", jaket diucapkan "Jake", kursi diucapkan "Kusi", odol diucapkan "Odo", pohon diucapkan "Poho", sisir diucapkan "Sisi", ulat diucapkan "Uma”, Wajan diucapkan "Waja”, dan yoyo diucapkan "Yoyo (lihat tabel 1).

Kosakata yang diucapkan oleh AZH pelafalannya berubah semakin baik dari treatment pertama dibandingkan dengan treatment terakhir. Terdapat $5(20 \%)$ kosakata yang pelafalannya lebih baik, diantaranya: (i) Kosakata Gelas, pada treatment pertama diucapkan "Gela" dan pada treatment terakhir diucapkan "Genas". Pengucapan kosakata ini dinilai lebih baik karena pada treatment terakhir sudah dapat mengucapkan lima huruf, walaupun masih belum tepat; (ii) Kosakata mawar, pada treatment pertama diucapkan "Mama" dan pada treatment terakhir diucapkan "Mamat". Pengucapan kosakata ini dinilai lebih baik karena pada treatmen terakhir sudah dapat mengucapkan lima huruf, walaupun masih belum tepat; (iii) Kosakata nenek, pada treatment pertama diucapkan "Nene" dan pada treatement terakhir diucapakan "Nenes". Pengucapan kosakata ini dinilai lebih baik karena pada treatment terakhir sudah dapat mengucapkan lima huruf, walaupun masih belum tepat; (iv) Kosakata vitamin, pada treatment pertama diucapkan "Vave" dan pada treatment terakhir diucapkan "Vimani". Pengucapan kosakata ini dinilai lebih baik karena pada treatment pertama baru mengucapkan dua suku kata dan huruf yang tepat baru dua huruf, sedangkan pada treatment terakhir sudah dapat mengucapkan tiga suku kata dan huruf yang tepat sudah lima huruf; (v) Kosakata zaitun, pada treatment pertama diucapkan "Zeta" dan pada treatment terakhir diucapkan "Zetu". Pengucapan kosakata ini dinilai lebih baik karena pada treatment pertama huruf yang benar baru dua huruf dan pada treatment terakhir sudah dapat mengucapkan tiga huruf yang benar (lihat tabel 1).

Kosakata yang diucapkan oleh AZH pelafalannya berubah semakin kurang baik dari treatment pertama dibandingkan dengan treatment terakhir. Terdapat 3 (11\%) kosakata yang perkembangan pelafalannya semakin kurang baik, diantaranya: (i) Kosakata celana, pada treatment pertama diucapkan "Cenana" namun pada treatement terakhir diucapakan "Cena". Pengucapan kosakata ini dinilai semakin tidak baik karena pada treatment pertama sudah dapat mengucapkan tiga suku kata dan terdapat 5 huruf yang sudah diucapkan walaupun masih belum tepat, sementara pada treatment terakhir hanya mengucapkan dua suku kata dan terdapat hanya 4 huruf yang sudah tepat; (ii) Kosakata daun, pada treatment pertama diucapkan "Dau" namun pada treatement terakhir diucapakan "Doho". Pengucapan kosakata ini dinilai semakin tidak baik karena pada treatment pertama sudah dapat mengucapkan tiga huruf yang benar, sementara pada treatment terakhir hanya 1 huruf yang benar; (iii) Kosakata lilin, pada treatment pertama diucapkan "Lili" namun pada 
treatement terakhir diucapakan "nini". Pengucapan kosakata ini dinilai semakin tidak baik karena pada treatment pertama sudah dapat mengucapkan empat huruf dengan benar, sementara pada treatment terakhir hanya 2 huruf yang benar (lihat tabel 1).

Terdapat juga kosakata yang diucapkan oleh $\mathrm{AZH}$ pelafalannya berubah dari treatment pertama dibandingkan dengan treatment terakhir, tapi tidak dapat dikatakan berkembang lebih baik atau sebaliknya. Terdapat 4 (15\%) kosakata yang perkembangan pelafalannya berubah dari treatment pertama dibandingkan dengan treatment terakhir, namun tidak dapat dikatakan berkembang lebih baik atau sebaliknya, diantaranya: (i) Kosakata quran, pada treatment pertama diucapkan "kukwa" namun pada treatement terakhir diucapakan "kuwa"; (ii) Kosakata robot, pada treatment pertama diucapkan "dobo" namun pada treatement terakhir diucapakan "wobo"; (iii) Kosakata tangga, pada treatment pertama diucapkan "tata" namun pada treatement terakhir diucapakan "taha"; (iv) Kosakata xilofon, pada treatment pertama diucapkan "sadofo" namun pada treatement terakhir diucapakan "sipapo". Keempat kosakata tersebut pengucapan pada treatment pertama dan terakhir memang berbeda, namun perbedaan tersebut pelafalannya tidak mengarah ke lebih baik atau lebih tidak baik (lihat tabel 1 ).

\section{Tingkat Kesulitan dalam Mengucapkan Kosakata}

Anak penyandang autis salah satu cirinya mempunyai kesulitan dalam mengucapkan kosakata dengan tepat atau benar. Demikian juga dengan $A Z H$, ada kosakata yang pelafalnnya dapat diucapkan dengan benar, ada kosakata pelafalannya hamper benar, dan ada juga kosakata yang pelafalnnya masih jauh dari benar. Dari 26 kosakata yang dilatih, hanya terdapat dua sukukata yang pelafalannya dapat diucapkan dengan benar, yakni kata "Api" dan "Yoyo". Terdapat juga beberapa kata yang pelafalannya hampir benar diucapkan (hanya ada kurang pengucapan pada huruf akhir), diantaranya: Ikan diucapkan "ika”, jaket ducapkan "jake”, kursi diucapkan "kusi”, odol diucapkan "odo", pohon diucapkan "poho", dan sisir diucapkan sisi. Demikian juga ada beberapa kosakata yang pelafalannya masih jauh dari benar, contohnya kosakata quran dilafalkan "Kuwa" dan kosakata vitamin dilafalkan "Vave" (lihat table 1)

Selain terdapat kosakata yang sulit diucapkan oleh $\mathrm{AZH}$, terdapat juga huruf yang belum dapat diucapkannya, yakni huruf "R" dan "Ng". Pada huruf "R" dapat ditunjukan pada kosakata Robot yang diucapkan "Dobo atau wobo". Sedangkan pada huruf "Ng" dapat ditunjukan pada kosakata Tangga yang diucapkan "Tata atau taha" (lihat tabel 1).

Orangtua, guru, dan terapis harus dapat memahmi kelebihan dan kekurangan anak autis dalam berkomunikasi. Beberapa anak autisme lainnya mengalami keterlambatan kemampuan berbahasa bahkan tidak mulai berbicara. Namun anak tersebut dapat belajar mengenai berkomunikasi dengan terapi. Perkembangan kemampuan berbahasa anak autism sangat beragam, begitu pula dengan hambatan yang dialami. Beberapa anak akan mengalami kesulitan dalam kemampuan berbahasa seperti dalam pemerolehan kosakata, namun ada beberapa anak memiliki kemampuan berbahasa yang unggul seperti penguasaan kosakata yang tinggi hingga mengalami kesulitan mengadakan komunikasi sederhana dengan anak seusianya (Hidayah, 2017).

\section{Tingkat Kesulitan dalam Mengingat Kosakata}

Saat melakukan treatment, jumlah instruksi pada setiap kosakata berbeda-beda antara satu kosakata dengan kosakata yang lainnya. Ada kosakata yang jumlah instruksi yang diberikan ke $\mathrm{AZH}$ hanya beberapa kali namun ada pula yang jumlah instruksinya berkali-kali baru $\mathrm{AZH}$ mengikuti instruksi tersebut. Berikut ini adalah tabel jumlah intruksi pada setiap kosakata dari treatment pertama sampai dengan treatment ke duapuluh.

Pada treatment pertama dibandingkan dengan treatment selanjutnya, jumlah instruksi yang diberikan

\begin{tabular}{|c|c|c|c|c|c|c|c|c|c|c|c|c|c|c|c|c|c|c|c|c|c|c|}
\hline \multirow{2}{*}{ No } & \multirow{2}{*}{ Kosakata } & \multicolumn{21}{|c|}{ Treatment Ke- } \\
\hline & & 1 & 2 & 3 & 4 & 5 & 6 & 7 & 8 & 9 & 10 & 11 & 12 & 13 & 14 & 15 & 16 & 17 & 18 & 19 & 20 & $\mathrm{Jmh}$ \\
\hline 1 & Api & 3 & 1 & 1 & 0 & 1 & 0 & 0 & 0 & 0 & 0 & 0 & 0 & 0 & 0 & 0 & 0 & 0 & 0 & 0 & 0 & 7 \\
\hline 2 & Bendera & 2 & 2 & 1 & 0 & 0 & 0 & 1 & 0 & 0 & 0 & 0 & 0 & 0 & 0 & 0 & 0 & 0 & 0 & 0 & 0 & 8 \\
\hline 3 & Celana & 2 & 3 & 1 & 0 & 1 & 1 & 1 & 1 & 0 & 0 & 2 & 2 & 1 & 3 & 0 & 1 & 0 & 1 & 0 & 0 & 23 \\
\hline 4 & Daun & 2 & 1 & 1 & 0 & 2 & 1 & 1 & 1 & 1 & 0 & 1 & 0 & 0 & 0 & 0 & 0 & 1 & 0 & 0 & 0 & 13 \\
\hline 5 & Ember & 4 & 2 & 1 & 3 & 2 & 1 & 0 & 0 & 0 & 0 & 0 & 0 & 0 & 0 & 0 & 0 & 0 & 0 & 0 & 0 & 15 \\
\hline 6 & Foto & 2 & 1 & 1 & 0 & 0 & 0 & 0 & 0 & 0 & 0 & 0 & 0 & 0 & 0 & 0 & 0 & 0 & 0 & 0 & 0 & 5 \\
\hline 7 & Gelas & 1 & 1 & 1 & 1 & 1 & 1 & 1 & 2 & 1 & 0 & 2 & 0 & 0 & 0 & 0 & 0 & 0 & 0 & 0 & 0 & 13 \\
\hline 8 & Harimau & 2 & 1 & 1 & 1 & 1 & 1 & 1 & 1 & 0 & 0 & 0 & 0 & 0 & 0 & 0 & 0 & 0 & 0 & 0 & 0 & 10 \\
\hline 9 & Ikan & 4 & 1 & 1 & 0 & 0 & 0 & 0 & 0 & 0 & 0 & 0 & 0 & 0 & 0 & 0 & 0 & 0 & 0 & 0 & 0 & 7 \\
\hline
\end{tabular}




\begin{tabular}{|l|l|l|l|l|l|l|l|l|l|l|l|l|l|l|l|l|l|l|l|l|l|l|}
\hline 10 & Jaket & 2 & 2 & 1 & 1 & 1 & 0 & 0 & 0 & 0 & 0 & 0 & 0 & 0 & 0 & 0 & 0 & 0 & 0 & 0 & 0 & 9 \\
\hline 11 & Kursi & 2 & 1 & 1 & 1 & 1 & 0 & 0 & 0 & 0 & 0 & 0 & 0 & 0 & 0 & 0 & 0 & 0 & 0 & 0 & 0 & 7 \\
\hline 12 & Lilin & 3 & 3 & 1 & 0 & 0 & 0 & 0 & 0 & 0 & 0 & 0 & 0 & 0 & 0 & 0 & 0 & 0 & 0 & 0 & 0 & 10 \\
\hline 13 & Mawar & 3 & 2 & 2 & 0 & 0 & 1 & 0 & 0 & 0 & 2 & 0 & 0 & 0 & 0 & 0 & 0 & 0 & 0 & 0 & 0 & 12 \\
\hline 14 & Nenek & 3 & 2 & 1 & 2 & 2 & 0 & 0 & 0 & 0 & 0 & 0 & 0 & 0 & 0 & 0 & 0 & 0 & 0 & 0 & 0 & 12 \\
\hline 15 & Odol & 1 & 1 & 1 & 2 & 2 & 0 & 0 & 1 & 0 & 1 & 0 & 1 & 0 & 0 & 1 & 0 & 1 & 0 & 0 & 0 & 13 \\
\hline 16 & Pohon & 3 & 1 & 1 & 1 & 1 & 3 & 1 & 1 & 1 & 0 & 0 & 0 & 0 & 0 & 0 & 0 & 0 & 0 & 0 & 0 & 14 \\
\hline 17 & Quran & 1 & 2 & 1 & 1 & 1 & 0 & 1 & 1 & 0 & 0 & 0 & 0 & 0 & 0 & 0 & 0 & 0 & 0 & 0 & 0 & 10 \\
\hline 18 & Robot & 3 & 1 & 1 & 1 & 1 & 0 & 2 & 1 & 0 & 1 & 1 & 2 & 0 & 1 & 1 & 0 & 0 & 0 & 0 & 0 & 17 \\
\hline 19 & Sisir & 4 & 1 & 1 & 1 & 1 & 0 & 0 & 0 & 0 & 0 & 0 & 0 & 0 & 0 & 0 & 0 & 0 & 0 & 0 & 0 & 9 \\
\hline 20 & Tangga & 1 & 3 & 2 & 1 & 1 & 1 & 0 & 1 & 0 & 1 & 0 & 0 & 0 & 0 & 0 & 0 & 0 & 0 & 0 & 0 & 14 \\
\hline 21 & Ulat & 2 & 3 & 1 & 0 & 0 & 0 & 0 & 0 & 0 & 0 & 0 & 0 & 0 & 0 & 0 & 0 & 0 & 0 & 0 & 0 & 9 \\
\hline 22 & Vitamin & 3 & 3 & 1 & 2 & 2 & 1 & 1 & 1 & 0 & 2 & 0 & 0 & 2 & 1 & 2 & 1 & 1 & 2 & 1 & 0 & 29 \\
\hline 23 & Wajan & 3 & 1 & 1 & 0 & 1 & 1 & 0 & 0 & 0 & 0 & 0 & 0 & 0 & 0 & 0 & 0 & 0 & 0 & 0 & 0 & 8 \\
\hline 24 & Xilofon & 3 & 3 & 1 & 0 & 1 & 0 & 0 & 0 & 0 & 0 & 0 & 0 & 1 & 0 & 0 & 0 & 0 & 1 & 0 & 0 & 13 \\
\hline 25 & Yoyo & 4 & 1 & 1 & 0 & 0 & 0 & 0 & 0 & 0 & 0 & 0 & 0 & 0 & 0 & 0 & 0 & 0 & 0 & 0 & 0 & 7 \\
\hline 26 & Zaitun & 3 & 3 & 1 & 0 & 0 & 0 & 0 & 0 & 0 & 1 & 0 & 0 & 0 & 0 & 0 & 0 & 0 & 0 & 0 & 0 & 11 \\
\hline Jumlah & 66 & 46 & 28 & 18 & 23 & 12 & 10 & 11 & 3 & 8 & 6 & 5 & 4 & 5 & 4 & 2 & 3 & 4 & 1 & 0 & \\
\hline
\end{tabular}

Keterangan:

0 : Memberikan instruksi hurufnya saja

1: Memberikan instruksi huruf dan kosakatanya sebanyak 1 kali

2: Memberikan instruksi huruf dan kosakatanya sebanyak 2 kali

oleh instruktur relatif banyak. Hal ini karena $\mathrm{AZH}$

baru mengenal gambar dan nama kosakata tersebut.

Misalkan pada kata "Api" di treatment pertama, instruktur memberikan instruksi sampai 3 kali baru sampai pada akhirnya AZH dapat mengikuti ucapan instrukturnya. Bahkan pada kata ember, ikan, sisir dan yoyo, instruktur memberikan instruksi sampai dengan 4 kali (lihat tabel2).

Jumlah instruksi pada setiap kosakata di sepanjang pemberian treatment diindikasikan sebagai tingkat kesukaran. Semakin banyak instruksi yang diberikan berarti semakin sulit kosakata tersebut diingat oleh AZH. Tingkat kesulitan kosakata dapat dilihat dari banyak sedikitnya pemberian instruksi oleh instruktur pada setiap kosakata. Sebagian kosakata mudah diingat oleh $A Z H$ dan sebagian lagi sulit diingat. Kosakata yang dinilai paling mudah diingat oleh AZH, diantaranya: Api, bendera. foto, ikan, jaket, kursi, sisir. Hal ini karena jumlah instruksi yang diberikan oleh instruktur kurang dari 10 kali kepada AZH dalam 20 kali treatment. Sedangkan kosakata seperti celana, robot, vitamin dinilai paling sulit diingat oleh $\mathrm{AZH}$. Hal ini karena jumlah instruksi yang diberikan oleh instruktur kepada AZH dalam 20 kali treatment, instruktur memberikan instruksi lebih dari 15 kali (lihat tabel 2).

\section{Perkembangan Durasi Waktu Melakukan Treatment}

Waktu pelaksanaan pemberian treatment kepada AZH tidak ditentukan jamnya. Namun, penentuan waktu pemberian treatment yakni pada saat AZH dalam keadaan tenang, sehingga mudah terjadi kontak mata antara $\mathrm{AZH}$ dengan gambar. Jadi jika kondisi $\mathrm{AZH}$ dalam keadaan tenang maka langsung

diberikan treatment baik diwaktu pagi hari, siang hari, malam hari, bahkan pernah dilakukan pada tengah malam (treatment ke-8 jam 02.00). Pada awalnya pemberian treatment dijadwalkan pada saat perut kenyang, namun tidak jarang waktu perut kenyang justru AZH menjadi sangat aktif sehingga tidak berhasil dilakukan treatment secara penuh, mengingat $\mathrm{AZH}$ tidak dapat konsentrasi dan susah untuk kontak mata dengan gambar pada saat pemberian instruksi. Berikut ini grafik perkembangan durasi waktu dari mulai terapi pertama sampai dengan terapi terakhir.

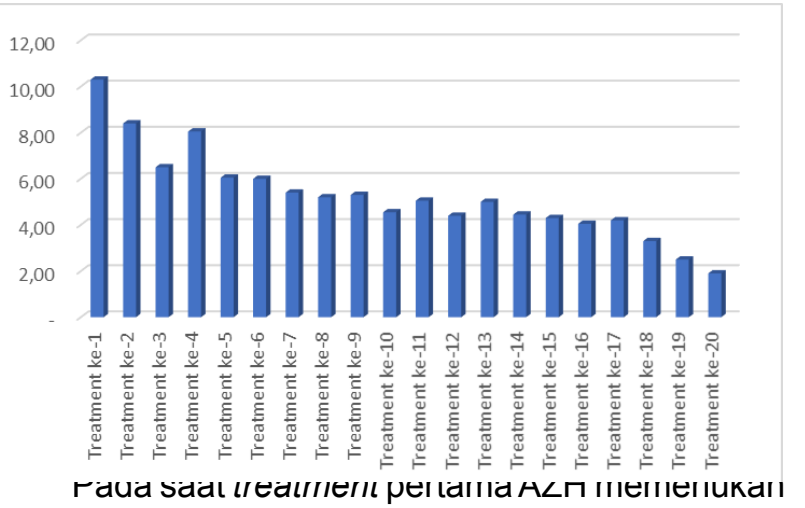
waktu sampai mengikuti instruktur untuk mengucapkan 26 kosakata yakni dalam waktu 10 menit. Pada treatment ke-2 dan ke-3 waktu pelaksannan treatment semakin berkurang menjadai 8 menit dan 6 menit. Namun pada treatmen ke-4 waktu yang dibutuhkan dalam melakukan treatment naik menjadi 8 menit lagi. Naik turunnya waktu pelaksanaan treatment sangat dipengaruhi oleh ketenangan AZH. Jika AZH kurang 
tenang akan memengaruhi konsentrasi dan kontak mata dengan gambar, sehingga waktunya menjadi bertambah. Namun secara umum treatment semakin lama memerlukan waktu semakin sedikit. Hal ini disebabkan karena $\mathrm{AZH}$ sudah merasa nyaman dan kenal dengan gambar yang diberikan (lihat grafik 1).

\section{PEMBAHASAN}

Dari hasil penelitian dapat disimpulkan bahwa penggunaan media gambar dapat mengembangkan penguasaan kosakata pada anak autis. Hal ini dapat terlihat dari empat indikator, diantaranya: perkembangan pengucapan kosakata, tingkat kesulitan dalam mengucapkan kosakata, tingkat kesulitan dalam mengingat kosakata, dan perkembangan durasi waktu melakukan treatment.

\section{Perkembangan Pengucapan Kosakata}

Perkembangan pengucapan kosakata dari sebelum melakukan treatment, pertama treatment dan terakhir treatment mengalami kemajuan. Sebelum melakukan treatment $\mathrm{AZH}$ belum dapat mengucapkan 26 kosakata yang diberikan. Pada pertama kali treatment AZH sudah mampu mengikuti seluruh perkataan yang diinstruksikan oleh instruktur, walaupun belum dapat menghafal. Setelah melakukan treatment sebanyak 20 kali $\mathrm{AZH}$ dapat menguasai seluruh kosakata tersebut dan dapat pula mengingatnya, walaupun masih banyak kosakata yang pengucapannya masih belum tepat/jelas. Hal ini senada dengan hasil penelitian yang dilakukan oleh Goa \& Derung (2017) yang menunjukkan adanya peningkatan komunikasi ekspresif anak dengan autis setelah menggunakan metode PECS (Picture Exchanges Communication System)

Perubahan ketepatan pelafalan kosakata dari treatment pertama dibandingkan dengan treatment terakhir yang diberikan kepada $\mathrm{AZH}$ dikelompokkan menjadi 4 bagian, diantaranya: pelafalannya tidak berubah sebanyak $54 \%$, pelafalannya berubah semakin lebih baik sebanyak $20 \%$, pelafalannya berubah menjadi kurang baik sebanyak $11 \%$ dan pelafalannya berubah namun tidak dapat dikatakan lebih baik atau lebih tidak baik sebanyak $15 \%$.

Perkembangan penguasaan kosakata $\mathrm{AZH}$ setelah dilakukan treatment menggunakan bantuan media gambar sejalan dengan hasil penelitian yang dilakukan oleh Puspitaningtyas (2018) yang telah menerapkan pada proses pembelajaran. Hasil penelitiannya menyebutkan bahwa "terjadi peningkatan dalam penguasaan kosakata pada anak autis dengan menggunakan media visual (gambar) dalam proses pembelajaran, hal ini menunjukan bahwa anak autis dapat memahami beberapa kosa kata melalui media visual (gambar) dan tampak ada perubahan yang lebih baik dalam berkomunikasi”. Demikian juga hasil penelitian yang dilakukan oleh Trisnawati dan Sujarwanto (2014) yang hasilnya menyebutkan "terjadi peningkatan kemampuan penguasaan kosakata anak autis dari nilai rata-rata pre-test 63 sebelum diberikan intervensi dengan menggunakan media visual (gambar) menjadi 73 pada rata-rata post-test atau sesudah diberikan intervensi menggunakan media visual (gambar)".

\section{Tingkat Kesulitan dalam Mengucapkan Kosakata}

Pengucapan kosakata $\mathrm{AZH}$ dalam treatment terlihat mempunyai tingkat kesulitan yang berbedabeda. Pada saat treatment ada beberapa kosakata dengan mudah diucapkan oleh $\mathrm{AZH}$ adapula yang sulit diucapkannya. Kosakata yang mudah diucapkan oleh AZH adalah yang mempunyai dua suku kata dan setiap suku kata terdiri dari dua huruf. Adapun kosakata yang mempunyai tiga sukukata, $\mathrm{AZH}$ kesulitan dalam mengucapkannya. Contohnya pada kata celana diucapkan "Cena", Vitamin diucapkan "Vave", dan Xilofon diucapkan "Sipapo". Untuk itu, langkah pertama kali mengajarkan kosakata pada anak autis adalah kosakata yang mempunyai dua suku kata dengan empat huruf, baru setelah itu yang lima huruf. Selain itu hindari kata yang ada huruf $\mathrm{R}$ dan $\mathrm{Ng}$, karena huruf tersebut tidak dapat diucapkan olehnya (lihat tabel 1).

Peran orangtua, terapis dan guru dalam menyelesaikan masalah kesulitan mengucapkan kosakata pada anak autis sangat tinggi. Orangtua, terapis maupun guru seringkali tanpa tidak sadar menghambat perkembangan komunikasi dengan memaksakan anak untuk belajar kosakata tertentu. Hasil penelitian yang dilakukan oleh Salman (2014) menyebutkan bahwa "faktor penghambat komunikasi anak autis dalam berkomunikasi terutama berasal dari lingkungan internal sekolah dan lingkungan internal keluarga." Untuk itu baik orangtua, terapis maupun guru harus memberikan treatment pembelajaran kosakata terhadap anak autis dimulai dengan kata yang mudah yakni yang mempunya empat huruf dan dua suku kata.

\section{Tingkat Kesulitan dalam Mengingat Kosakata}

Tingkat kesulitan dalam mengingat kosakata berbeda-beda, pada saat treatment ada beberapa kosakata dengan mudah diingat oleh $\mathrm{AZH}$ adapula yang sulit diingat. Namun secara umum semakin lama dilakukan treatment semakin mudah $\mathrm{AZH}$ dalam 
mengingatnya. Hal ini dapat ditunjukkan dengan jumlah instruksi yang diberikan oleh instruktur kepada AZH pada setiap treatment.

Antara treatment pertama sampai dengan treatment terakhir jumlah total pemberian instruksi berbeda-beda. Pemberian instruksi paling banyak pada treatment pertama yaitu dengan total jumlah instruksi sebanyak 66 kali. Sedangkan yang paling sedikit pada pemberian treatment yang ke-20. Pada treatment ke20, Instruktur samasekali tidak memberikan instruksi secara lengkap, hanya memberikan instruksi hurufnya saja, kemudian AZH langsung mengucapkan dengan kosakata lengkap. Misalkan instruktur mengucapkan A kemudian AZH langsung menjawab "Api". Hal ini dapat disimpulkan bahwa semakin banyak treatment, AZH juga semakin mengingat kosakata yang diberikan. Selain itu, kosakata yang dianggap mudah diingat yakni yang mempunyai dua suku kata dan pernah melihat bentuk fisiknya, sedangkan yang sulit diingat adalah kosakata yang mempunyai tiga suku kata dan tidak melihat bentuk fisiknya. Untuk itu, pemberian bentuk fisik pada saat terapi dapat membantu tingkat pemahamannya.

Perkembangan Durasi Waktu Melakukan Treatment

Perkembangan durasi waktu melakukan treatment semakin memerlukan durasi waktu yang lebih rendah. Hal ini dikarenakan AZH sudah mulai familiar dan hafal kosakata yang diberikan. Hal ini sejalan dengan Howlin (2007) yang menemukan bahwa kebanyakan anak dengan autis memiliki ingatan visual baik (visual learners), yaitu mereka dapat menghafal dengan mudah, dapat memproses banyak materi dengan cepat, dan sangat teliti dalam mengerjakan tugas.

Kondisi ketenangan anak sangat memengaruhi kualitas hasil dari setiap treatment. Untuk itu, jangan melakukan treatment dalam kondisi anak kelelahan, ngantuk, ataupun sedang aktif bergerak. Hasil treatment tidak akan ada bahkan kebalikan, si anak akan menjadi trauma untuk melakukan treatment. Hal ini sejalan dengan hasil penelitian yang dilakukan oleh Pradini (2012) dengan hasil penelitiannya "kondisi mood atau suasana hati anak autis sangat mempengaruhi proses komunikasi antara orang tua dan anak autis. Komunikasi dengan anak autis dibangun kembali setelah mood anak telah stabil dengan beragam cara, seperti memeluk atau memberi mainan kesukaan anaknya".

\section{PENUTUP}

Simpulan hasil penelitian ini memperlihatkan terdapat pengaruh penggunaan media gambar dalam meningkatkan penguasaan kosakata pada anak autis. Hal ini dapat ditunjukkan dari kemampuan AZH yang menguasai seluruh kosakata yang diberikan. Berikut ini adalah ringkasan hasil treatment yang dilakukan kepada AZH: (i) Terdapat perkembangan pengucapan kosakata dari sebelum melakukan treatment, pertama treatment dan terakhir treatment; (ii) Kosakata yang mudah diucapkan oleh $\mathrm{AZH}$ adalah yang mempunyai dua suku kata dan setiap suku kata terdiri dari dua huruf. Adapun kosakata yang mempunyai tiga sukukata, AZH kesulitan dalam mengucapkannya; (iii) Kosakata yang dianggap mudah diingat yakni yang mempunyai dua suku kata dan AZH pernah melihat bendanya, sedangkan yang sulit diingat adalah koskata yang mempunyai tiga suku kata dan tidak melihat bentuk fisiknya; dan (iv) Perkembangan durasi waktu melakukan treatment semakin lama memerlukan waktu semakin sedikit.

Saran dalam penelitian ini adalah pemberian latihan pengucapan kosakata yang pertama kali yakni dengan memilih kata benda yang mempunyai dua suku kata dengan empat huruf. Kemudian meningkat dilatih dengan kata benda yang mempunyai lima huruf. Selain itu hindari kata yang ada huruf $R$ dan $\mathrm{Ng}$, karena huruf tersebut susah diucapkan. Usahakan anak autis melihat benda aslinya, misal kata ikan ditunjukkan benda asli berupa ikan sesungguhnya sesuai dengan gambar. Adapun waktu pelaksanaan treatment diberikan ketika anak dalam kondisi tenang

\section{DAFTAR PUSTAKA}

Arsyad, A. (2010). Media Pembelajaran. Jakarta: Rajawali Pers.

Boham, S. E. (2013). Pola Komunikasi Orang Tua Dengan Anak Autis (Studi Pada Orang Tua Dari Anak Autis Di Sekolah Luar Biasa AGCA Center
Pumorow Kelurahan Banjer Manado). Journal Acta Diurna. 2 (4)

Freed, J. \& Parsons, L. (1997). Right-brained Children in A Left-brained World. New York: Simon and Schuster. 
Goa, L \& Derung, T, N. (2017). Komunikasi Ekspresif dengan Metode PECS bagi Anak dengan Autis. Jurnal Nomosleca. 3 (2). 625 - 634

Hidayah, O, D, N. (2017). Autisme: Karakteristik dan Strategi. Surabaya: Pustaka Media Guru.

Howlin, P., Gordon, R. K., Pasco, G., Wade, A. \& Charman, T. 2007. The effectiveness of Picture Exchange Communication System (PECS) Training for teachers ofchildren with autism: A pragmatic, group randomized controlled trial. Journal of Child Psychology and Psychiatry. 48 (5).

Kidd, S, L. (2013). Anakku Autis, Aku Harus Bagaimana? Langkah Awal Mengatasi Autism pada Anak. Jakarta: PT Bhuana IImu Populer Kelompok Gramedia.

Pradini, D, N, A. (2012). Memahami Komunikasi Antarpribadi Orang Tua Dengan Anak Autis Dalam Memberikan Pendidikan Seksual Pada Masa Puber. Skripsi tidak diterbitkan. Semarang: Universitas Diponegoro.

Puspitaningtyas. A.R., \& Pratiwi, V. (2018). Penguasaan kosakata pada anak autis menggunkan media visual. Conference on Innovation and
Application of Science and Technology (CIASTECH 2018) Universitas Widyagama Malang. Seminar Nasional Hasil Riset, 229-236.

Putri, H, J. (2018). Metode Pembelajaran dan Pengembangan Kemampuan Verbal bagi Anak Autis. Journal Unimed. 69 (35).

Salman. (2014). Pola Komunikasi Orangtua dalam Mengatasi Kesulitan Berkomunikasi Anak Autis. Jurnal Jom FISIP, 1 (2), 1 - 13.

Sitompul, H, U, M. (2013). Proses Komunikasi Interpersonal Antara Terapis Dengan Anak Autis Di Esya Terapi Center Sidoarjo Dalam Proses Terapi Wicara. Jurnal e-komunikasi, 1 (3), 1 - 10. Sunanto, Juang; Takeuchi, Koji; dan Nakata, Hideo. (2005). Pengantar Penelitian dengan Subyek Tunggal. Tsukuba: CRICED University of Tsukuba

Trisnawati, W., \& Sujarwanto. (2014). Penggunaan Media Visual terhadap Kemampuan Penguasaan Kosakata pada Anak Autis. Jurnal pendidikan khusus, 9 (1).

Wijayakusuma, H. (2008). Psikoterapi Untuk Anak Autisma. Teknik Bermain Kreatif Non Verbal dan verbal, Terapi Khusus untuk Autisma. Jakarta: Pustaka Populer Obor. 